\title{
STATE ADMINISTRATION FORMATION OF REGIONAL HUMAN DEVELOPMENT IN UKRAINE
}

\author{
Oksana V. Shinkaryuk \\ Bukovina University, Chernivtsi, Ukraine
}

(C) MESTE NGO

JEL Classification: H83, 015

\begin{abstract}
The article highlights the stages of public administration formation of regional human development in Ukraine. Features native methods of calculation of regional human development index (RHDI) are analyzed and the results of their application are assessed. In the context of scientific methods it is emphasized on the minimum set of indicators that reflect key opportunities to provide regional processes of human development. The expediency of using the results of RHDI ratings are motivated for substantial improvements in the efficiency and effectiveness of economy state regulation, primarily to prioritize, scope and structure of the financing components of human development in developing medium- and long-term plans and programs for socio-economic development. The author argues that in the public administration formation of regional human development in Ukraine expenditure responsibilities of local authorities in the socio-economic development of the regions is advisable to specify and regulate on the basis of territorial reproductive processes. The indicators of financing of human development in the region (100 thousand of population) will become sum of local budgets for each component of territorial reproduction processes. Assessment of efficiency, economy and the budget mechanism effectiveness of Human Development Programs financing at the national and regional levels is appropriate to be carried out by the technique of the International Centre for Policy Studies (Ukraine), which was developed with the participation of experts of the Canadian International Development Agency (CIDA).This technique allows us to estimate the potential economic growth of regions and changes in quality of life there. The author proposed a number of measures that are intended to provide further scientific studies, practical testing and implementation of conceptual and methodological provisions of planned analytical work on financing human development in the regions of Ukraine.
\end{abstract}

Keywords: public administration, state regional policy, Regional Human Development Index (RHDI), budget management mechanism, forecasting, planning, financing, National and Regional Human Development programs.

\section{INTRODUCTION}

Address of the author:

Oksana V. Shinkaryuk

奉” o_kuzmovich@rambler.ru
Ukraine was the first country in Central and Eastern Europe as well as among the CIS countries to adopt the Concept of human development as an organic part of the Concept of 
sustainable development on a global and national dimension and a basis of civilized progress (Yaroshenko, Scientific and practical commentary to the Budget Code of Ukraine, 2011).

United Nations Development Programme (UNDP) in 1990 published their annual global report on human development, and estimates human development index (HDI) for Ukraine were first included in the Global Human Development Report 1993, ranking $45^{\text {th }}$ out of 169 countries and territories.

In 1995, it was first published National Human Development Report in Ukraine, prepared under the auspices of UNDP, which from that time prepared every two years.

United Nations Development Programme (UNDP) have been publishing their annual Global Report on human development since 1990, and Human Development Index (HDI) calculations for Ukraine were first included in the Global Human Development Report in 1993, ranking $45^{\text {th }}$ out of 169 countries and territories.

In 1995, it was first published National Human Development Report in Ukraine, prepared under the auspices of UNDP, and that have been preparing every two years since that time.

\section{THE STUDY}

\subsection{Methods of measuring regional human development in Ukraine and results of their application}

Public administration formation of regional human development in Ukraine is carried out at the appropriate stages, including:

- preparation of information provision as a part of human development rate stimulators and rate destimulators being grouped by development aspects;

- development of methodical maintenance with indicators definition and algorithms for ratios calculation;

- implementation of registration and accounting of human development indicators in the national statistical base;

- implementation of analytical assessments of national and regional human development ranking political subdivisions.
Nationally, the Human Development Index (HDI) is calculated according to the methodology of United Nations Development Programme (UNDP) for the data on health, education and welfare. Health characteristics is given by the average life expectancy rank at birth, education characteristics is given by literacy performance of adults and enrollment (school and post-secondary) its respective age groups, wealth characteristics is given by GDP at purchasing power parity per capita (Libanova, 2006).

In Ukraine since 1999 it has been calculated Regional Human Development Index (RHDI) according to administrative-territorial system: the 24 administrative regions, the Autonomous Republic of Crimea, Kyiv and Sevastopol.

Methodology for regional human development index is also based on a minimum set of indicators that reflect key features to ensure the whole process of human development in the area: living a long and healthy life (measurement - longevity); acquire, enhance and update knowledge (measurement-education); access to livelihoods, providing a decent standard of living (measurement - the material standard of living). The method of calculation was adopted in 2001.

9 major aspects generalizing indicators of regional human development (demographic development, labor market development, material well-being of the population, living conditions of the population, level of education, and health status, social environment, ecological situation, financing of human development) were determined in calculating RHDI.

Using the proposed technique ensured the validity of socio-economic development comparisons of certain regions of Ukraine, scientific support for the systematic calculation of human development index of regions, the definition of each region on a universal scale, which allows you to perform methodologically correct comparison of both integral index and for each of the 9 indices of certain aspects in human development (Kalachova, 2011).

That is because human development indicators are the indicators of the public sector, they serve as the basis of the formation mechanism of the balanced budget indicators for sustainable 
development of the country based on national values.

Every aspect of human development indicators is consistent with a single unit, forming a system of human development indicators in regions. An outline of integral human development index is included with the 3-stage process according to the 3-level hierarchical system performance.

According to the Global Human Development Report, 2010 Human Development Index value of Ukraine was equal to 0.710 , which put the country on the 69th position in the world out of 169 countries and territories.

In recent years Ukraine has made progress in human development, as measured by the updated $\mathrm{HDI}$ which is to be a summary measure that estimates the long-term progress in three key areas of human development: the ability to live a long and healthy life, access to knowledge and gross domestic income (GDI) per capita.

Between 1990 and 2010 the HDI value in Ukraine increased from 0.690 to 0.710 , i.e. $3 \%$, or an average of $0.1 \%$ per year. During this period life expectancy at birth in Ukraine has decreased by about one year, mean years of schooling increased by more than two years and expected years of schooling - and more than two years. Gross National Income (GNI) per one person in the country has decreased by $28 \%$.

According to the Human Development Report, 2013 "The rise of the South: human progress Diverse World", the value of Ukraine's HDI for 2012 is 0.740 , which puts the country at position 78 out of the 187 countries and territories. From 1990 to 2012 the value of the HDI for Ukraine increased from 0.690 to 0.740 , i.e., $5 \%$ or an average of $0.4 \%$ per year. Though HDI in 2012 Ukraine belongs to the countries with high human development, this figure is well below the average value of the high human development (0.900).

Human Development Index in Ukraine is below average (0.717) in Europe and Central Asia. "Neighbors" of Ukraine according to this indicator (i.e. countries rated close HDI and population) are Kazakhstan and the Russian Federation, which occupy respectively 66 and 65 in the rankings (Kalachova, 2011).
As a result of ratings in 2011 three groups of regions have been identified taking into account 9 major aspects of the State Statistics Service of Ukraine:

- leading regions, which rank first five places according to the results of the RHDI calculation;

- core group of regions (18 regions) which rank accordingly from 6 to 23 places according to the results of the RHDI calculation;

- regions-outsiders which rank 4 last places according to integral calculations.

First place by a wide margin, according to the 1999-2011 years, surely is occupied by Kyiv, which belongs to the first position by the integral index of demographic development, material wellbeing, the living conditions of the population, the level of education and human development funding. The next place is the city of Sevastopol (first place in the labor market and health care, the second position by the demographic development, education and living conditions of the population, a high place for financing human development and material well-being). Third place was taken by Kharkov region: the second position in the ranking for the labor market, the third one by level of education; fairly high places in terms of material wealth, living conditions and health. But in absolute terms the index of dominance is not as expressive as the position of Kyiv (0.674).

Kiev region is among the five leaders of the demographic development indices, material wellbeing, living conditions, education and finance human development. Negative aspects in the general index of the region are the social environment and the development of the labor market.

Poltava region occupies the 4th place for financing human development index and has a relatively large value for the assessment of other units. It should be noted that the area has virtually no components that significantly affect its development.

On the opposite side of the scale is taken by Donetsk region $\left(27^{\text {th }}\right.$ seat), Luhansk region $\left(26^{\text {th }}\right.$ place) and Zhytomyr (region $25^{\text {th }}$ ) are far behind the human development index of most regions of Ukraine. It should also be noted that in recent years it has been worsened the position of 
Vinnitsa region (2005 $21^{\text {st }}-26^{\text {th }}$ places) and Zhytomyr region (25th place in 2010 - the lowest position in all the years of payment). These areas were slightly ahead of outsiders on a single scale of human development integrated regional index in 2011.

In order to stabilize and improve the situation in the social sphere of the last two groups of regions it is a clear need to conduct in-depth analysis of the human development factors for all segments of its hierarchical structure and develop a comprehensive system of social activities aimed at increasing the value of skilled labor; ensuring the right to work, social security, education, health and housing; development of social infrastructure, and the availability of basic social services; supporting families, mothers and children policies.

In 2012 a new measurement of regional human development in Ukraine was approved. Calculation of regional human development index included 33 indicators that combined 6 units in accordance with the basic aspects of human development: reproduction; social status; comfortable life; well-being; decent work; education. Experimental estimates of regional human development by this method have been carried out since 2004.

Calculations of the Human Development Index allow building a single scale, which rank all regions of Ukraine. The exact value of the integral index (or indices that characterize some aspects of human development) has no economic interpretation i.e. it is only important a place that belongs to each region of Ukraine on a single scale.

Because of this, the results of RHDI ratings were used for substantial improvements in the efficiency and effectiveness of economy state regulation, primarily to prioritize, scope and structure of the financing components of human development in developing medium-and long-term plans and programs for socio-economic development.

The strongest influence on determining the location of the region on a single scale index of human development is education, living conditions and material welfare. The least visible is the impact of labor market indicators. Perhaps it is because the indirect labor market situation determines the location of the region on the scale of the human development index over material wealth and - to a lesser extent - in living conditions.

Based on the results of Human Development Index rating by the State Statistics Service of Ukraine in 2012 the following results were obtained for the 6 main aspects of regional human development.

First place during the years 2004-2009 was held by Zakarpattia region, which occupied the first position by a combined index of comfortable living. In 2010-2012 the first place belonged to Kharkiv region. High grade of this region is explained by the best indicators of education and welfare. The next place is held by Chernivtsi region (the first position on the development of social protection and well-being). Instead, Zhytomyr region (the worst welfare, education, labor market and reproduction), Kirovograd region (low values reproduction and social environment) and Kherson region (low values of the social environment, welfare and reproduction) are located on last place.

Thus, the results of HDI regional calculations can serve as a basis for identifying key issues and priorities of each region. Quantitative values of the index components to some extent also reflect the effectiveness of the public authorities on human development of the region, especially in Ukraine's transition to a parliamentary-presidential model of government building, administrative-territorial reform and the associated increasing role of local public authorities and local governments (Vernadsky, 1988)(Kalashnikova, 2003).

\subsection{The public administration formation of regional human development in Ukraine}

Differentiation of Regions in Ukraine in terms of human development is the most comprehensive indicator for evaluating the effectiveness of state regional policy which is implemented by the basic building blocks of human development.

Scientific and practical solution of the problems of human development state regulation in Ukrainian regions is carried out as part of programs and socio-economic development, state and local 
budgets, as well as in the context of public-private partnerships. In addition to accounting and analytical assessment of actual levels RHDI it is projected the transition to forecasting, planning and financing in the national and regional programs of human development, which should be among the central budget programs at national and regional levels of social and economic processes regulation.

The human development financial component more than any other, characterizes the thrust of national regional policy. It was set up a list of indicators to characterize this aspect in the preparation of the National Human Development Report (every two years) and annual analytical "Regional Human Development", which characterize the amount of social expenditures of local budgets, the structure of local budgets and transfers to the State budget:

- local budgets disbursement for education, UAH per person;

- local budget disbursement on healthcare, UAH. per person;

- local budget expenditures on social protection, UAH per person;

- the State budget transfers, UAH per person;

- the share of education disbursement in total social expenditures of local budgets, \%;

- share of health expenditure in total social expenditures of local budgets, \%;

- share of social protection expenditures in total social expenditures of local budgets, \%;

- correlation of State budget transfers to social expenditures of local budgets.

In the public administration formation of regional human development in Ukraine expenditure responsibilities of local authorities in the socioeconomic development of the regions in accordance with the administrative-territorial system of Ukraine is advisable to specify and regulate on the basis of the following classification of territorial reproductive processes including:

- the material base reproduction of social services (housing, utilities, education, health, social protection and social security, culture, art, media, physical culture and sports);

- reproduction of communication objects, telecommunication and information;

- reproduction of production and road transport infrastructure;
- protecting the environment and ensuring integrated and sustainable environmental management.

Formation of the innovative Ukrainian society in the future will be based primarily on generating and using new knowledge. Therefore, social investment in intellectual capital will turn into the most efficient way of placing state and local budget resources (Yaroshenko, Scientific basis for further development and improvement of the conceptual provisions of the revised Budget Code of Ukraine. Scientific and practical commentary to the Budget Code of Ukraine, 2011).

\subsection{Budget management mechanism of national and regional human development}

The modern Ukrainian realities have paradigm shift preconditions in budget management mechanism of national and regional development for the transition from the application of the theory of employment, economic growth and material prosperity for the use of terms and concepts of human development indicators. Thus the socioeconomic development figures of the region are not only a function solely of natural resources, capital, organizational and technical factors, but also an outcome of the social capital - education, health, culture and historical heritage of the population, awareness and implementation of cleaner production management in business activities and more.

Regions differentiation in Ukraine in terms of human development is the most comprehensive indicator for evaluating the effectiveness of state regional policy, which is implemented by the basic building blocks of human development: public health and demographics, education and development of the education system, labor market conditions and standard of living.

Targets figures of socio-economic development of the region and the national economy, as a whole are figures of life standard and quality level. That they are the best to reflect the adequacy of the social orientation of all the changes taking place in the region.

The standard of living - is a composite index that characterizes the material and spiritual achieved needs of individuals and society as a whole, 
reflecting ultimately the well-being of the population. Moreover, the structure of the material and spiritual needs of man is adequate to the structure of human activity by starting point and the goal.

Life standard is a socially accepted standard of living. In some countries there are official specific life standards of living and, in addition, each social group and community and well everyone has their own subjective standard. Life standard also changes over time, but this change occurs as discrete qualitative change in the socio-economic system.

Quality of life is the value of life and the accepted standard. This criterion shows the degree of needs satisfaction, and as needs arise only if there are potential opportunities, and quality of life actually reflects the equilibrium level of socioeconomic systems and characterizes the level of social tension.

Ideally, management of social and economic development must be based on the objective function, which is an indicator of quality of life in balanced budget mechanism.

Implementation of the revised Budget Code of Ukraine (2010) is focused on the use of social groups in the formation of a new budget mechanism balanced by state management on the basis of the national system of values that will ensure the preservation of various individual characteristics of the population in each region, its moral principles: spirituality and education, historical heritage and territorial integrity, customs and traditions, culture, and philosophy, peaceful mentality and ethical values, as well as interemergent regions development as a single organic unit (Yaroshenko, Scientific basis for further development and improvement of the conceptual provisions of the revised Budget Code of Ukraine. Scientific and practical commentary to the Budget Code of Ukraine, 2011).

Balanced management of sustainable state development on the basis of national values involves, in the future, the determination of maintenance costs and reproduction of the material resources and social infrastructure of a particular region to be supplied with their own financial resources that are accumulated in the local budget and transfers from the state budget were mainly appointed for ensuring common standards of living in different regions of the state with a focus on the implementation of EU social standards.

That is, if the priorities of socio-economic development of regions, districts, cities and towns is determined by the Programme of human development in region, then the formation of finance local sources will be determined in accordance with the local authorities expenditure responsibilities to ensure local economic cycle of reproduction processes. And the rates of funding of human development in the region (100 thousand people) are local budgets expenditures for each component of the local reproductive processes.

Assessment of efficiency, economy and the budget mechanism effectiveness of Human Development Programs financing at the national and regional levels is appropriate to be carried out by the technique of the International Centre for Policy Studies (Ukraine), which was developed with the participation of experts of the Canadian International Development Agency (CIDA).

This technique allows us to estimate the potential economic growth of regions and changes in quality of life there. In the current study the benchmarking was conducted for 36 indicators, 6 9 per each of the areas. Indicators are selected in such a way as to describe the most important parameters in that area, measuring resources, the costs, efforts and policy outcomes. And 63 countries was the value of the sample for comparative analysis.

First, the factors affecting the change in the capital stock (investment incentives, the movement of foreign capital and tax policies) are analyzed as well as labor supply (especially demographic factors) and total factor productivity (education, health, research and development, etc.). Further, the changes in the quality of life assessment in the regions to be carried out and which are based on the following definition of the relevant fields, parameters and indicators.

Welfare area is characterized by the following parameters (economy, efficiency, innovation) and by indicators (GDP per capita, unemployment, business climate, energy efficiency, information, research funding, and availability of scientists). 
Society area is reflected by the following parameters (roughness, security threats) and indicators (income inequality, gender inequality, the number of murders, and the number of robberies, demographic stress, unemployed youth, and corruption).

The health system area includes the following options (health, morbidity, and lifestyle) and indicators (life expectancy, the gender gap in life expectancy, infant mortality, the HIV incidence, TB incidence, health care financing, medical supply, alcohol consumption, smoking tobacco).

The education area is characterized by the parameters (money, resources) and indicators (the number of foreign students, the schooling years average, corruption, education funding, teachers supply, the labor force with higher education).

Environment area is displayed by the loading parameter and indicators: greenhouse gases, $\mathrm{CO}_{2}$ emissions, $\mathrm{SO}_{2}$ emissions, $\mathrm{NO}$ emissions, water quality, and the impact of the environmental situation on life duration, protected areas, and environmental regulation.

We know that over the last 30 years in developed countries there is to be high social factors productivity (SFP) that provides 1/3-1/2 GDP growth, and is characterized by a greater influence on the output of goods and services compared to the "classical" factors - labor and capital.

The benchmarking results identified four leading regions - cities of Kyiv and Sevastopol, and two areas - Kharkiv and Zakarpattia. Meanwhile, as the first place by Kyiv is not surprising thing, the region leaders took the first places due to acquisitions only in some areas of quality of life. For example, Zakarpattia region, having the second lowest GDP per capita, obtained good results in the public health area and society area. Kharkiv region showed strong indicators in education and welfare.

Improving the quality of life in the region is not possible without the active involvement of local governments. Government initiatives and local authorities of regional cohesion are designed to help the outsider regions, on the one hand, and preserving incentives for the development of leader regions - on the other.
It is well-known that social development index is formed by averaging the three global indices: Quality and Safety of life Index; Human Development Index; Society Index based on knowledge, or K-society.

Considered conceptual position of forming a regional system of human development that is proposed to assess by Quality and Safety of life Index.

Quality and Safety of life Index is formed by the following nine indicators: GDP per capita in purchasing power parity; population life expectancy; political stability and security rating; number of divorced families per 1,000 population; public activity level (activity of trade unions, NGOs, etc.); difference with latitude between climate warmer and colder regions of the country; unemployment rate of the country; level of political and civil liberties in the country; the ratio between the average wages of men and women.

Human Development Index is formed by three indicators: population life expectancy; level of the population education and standard of living, as measured by GDP per capita at PPP.

Society Index based on knowledge, or K-society Index is defined by three main indicators: the intellectual assets of society; the future development of society and the quality of society. In turn, these indicators are formed by using 15 sets of data on the coverage of youth education and information, investment climate in the country, corruption, inequality and the distribution of social benefits, child mortality and others.

Thus, the introduction of the revised Budget Code of Ukraine, using principles and indicators of Conception and Human Development Programs, has appropriate methodological, analytical and information support. The orientation in fiscal policy on the continued expansion of opportunities to meet the physical and spiritual needs of the Ukrainian people is an irreversible path of social progress of our country, which confirms the high dynamism and improvement of the budgetary process.

\section{CONCLUSIONS}

Further scientific studies, practical testing and implementation of conceptual and methodological provisions of planned analytical work on financing 
human development in the regions of Ukraine provide:

- standardization and improvement of appropriate stimulant and destimulant indicators, their indicators for the evaluation and analysis of human development component, the structure of their relationship, algorithms and methods of calculation;

- regulate the manner and timing of rating assessments of human development trends in the region, as well as the relationship between human development status and practice of funding from state and local budgets;

- prioritization of human development at the National and Regional Programs, the structure of their relationship on the basis of construction of intersectoral balance or scheme where the priority indicators are their purpose while being the indicators of social efficiency in other budget programs;

- development of information and statistical support planning, analysis and control funding of all human development components at the national and regional levels.

- Forecasting functions, programming, planning and financing introduction is preceded by designing and setting up the components of economic organizational mechanism as the basic subsystems of human development public administration in Ukraine (Yaroshenko, Scientific basis for further development and improvement of the conceptual provisions of the revised Budget Code of Ukraine. Scientific and practical commentary to the Budget Code of Ukraine, 2011). In particular, it is assumed that:

- the Cabinet of Ministers of Ukraine is the development organizer, coordinator and responsible executor of the National and Regional Human Development programs, and the Ministry of Finance of Ukraine is the main budget funds manager of these programs;

- human development aspects of at the national and regional levels are features of subprograms in the National and Regional Human Development programs;

- every aspect of human development indexes corresponds to a single unit, forming a of the National and Regional Human Development programs;
- the National Human Development program financing is carried out by the State Budget of Ukraine, hence Regional programs is carried out by the State and local budgets in Ukraine;

- the National and Regional Human Development programs are consistent with the strategic objectives of socioeconomic development of the state and the regions for the following two periods of the planned;

- the budget policy for the next budget period is based on forecasting and policy instruments for economic and social development and should incorporate the objectives of the National and Regional Human Development Programs, which are substantiated in The Cabinet of Ministers of Ukraine;

- key budget spending units clarifies the main purpose of the activities and form budget requests based on the needs of the tasks of the National and Regional Human Development programs and subprograms according to their mission;

- Ministry of Finance of Ukraine analyzes budget requests of budget spending units in accordance with the objectives of the subprograms to the objectives of the National and Regional Human Development programs;

- State Budget of Ukraine and SocioEconomic Development Program includes the analyzes of National Report «Human Development in Ukraine» and analyzes «Regional Human Development» for prior periods as compared with other countries, and also projects of the National and Regional Human Development programs that train and develop the Ministry of Economic development and Trade of Ukraine, Ministry of Finance of Ukraine and the State statistics Service of Ukraine with the National Academy of Sciences of Ukraine;

- projects of the National and Regional Human Development Programs are based on a list of key issues and priorities of socio-economic development of the planning period, and the medium-term prospects, which are initiated and justified 
by central and local executive authorities and local government;

- calculation results of RHDI components to some extent reflect the performance of activities of state and local authorities and local governments for reproduction of the human potential of the region;

- correlation analysis of the state budget social transfers to social expenditures of local budgets allows to assess the level of state financial self-reliance and local executive authorities and local government in human development;

- simple reproduction of the human potential of the area in Regional Human Development Programs is carried out within their own financial resources of local governments, and advanced playback is carried out within the National Human Development Program based on transfers from the central to local government;

- the calculating results of Regional Human Development Index (RHDI) is the basis for identifying key issues and priorities of socio-economic development of each region;

- an effective regional development strategy formation provides the inclusion of indicators in the Regional Human Development Programs:

- covering all levels of education areas that characterize the education equality of each age group;

- the developing the living conditions of the population;

- improving welfare.

- social transfers in the state and local budgets relations are intended to ensure common standards of living in different regions of the state;

- scope and structure of transfers from the central to local budgets are based on comparative assessment of socioeconomic development of Ukraine: demographic development; the labor market; material well-being of the population; living conditions of the population; level of education; status and health; social protection; environmental situation;

- the National and Regional Human Development Programs projects should include a comprehensive system of social activities aimed at:

- increasing in the cost of skilled labor;

- ensuring the right to work, social security, education, health and housing;

- developing of social infrastructure and accessibility to basic social services;

- supporting policy of families, mothers and children;

- effectiveness of state and private partnerships and budget funding mechanism of the financing human development is estimated by potential regional growth and changes in quality of life there.

The legal regulation of scientific and methodological support of state administration formation of regional human development in Ukraine is scheduled to be carried out by clarifying and amending the Verhovna Rada of Ukraine, especially the Budget Code of Ukraine, Laws of Ukraine "On Local Government in Ukraine" and "On Local State Administrations".

\section{WORKS CITED}

Kalachova, I. (2011). Regional Human Development. Statistical Bulletin. Kyiv: State Statistics Service of Ukraine.

Kalashnikova, L. (2003). Regional Finance: the nature, content and assessment (methodological aspect). Problems and prospects of Ukraine's financial system. Proceedings of IAPM.9, pp. 4850. IAPM.

Libanova, E. (2006). Human Development in Ukraine: opportunities and areas of social investments (collective research and analytical monograph). Kyiv: Institute for Demography and Social Studies of NAS of Ukraine, State Statistics Committee of Ukraine. 
Vernadsky, V. (1988). Philosophical thoughts of naturalistic. Moscow: Nauka.

Yaroshenko, F. (2011). Scientific and practical commentary to the Budget Code of Ukraine (2nd revised edition ed.). Kyiv: State educational and scientific institution "Academy of Financial Management", Ukrainian State University of Finance and International Trade. Retrieved from http://www.rulit.net/books/naukovo-praktichnij-komentar-byudzhetnogo-kodeksu-ukraini-read277128-1.html

Yaroshenko, F. (2011). Scientific basis for further development and improvement of the conceptual provisions of the revised Budget Code of Ukraine. Scientific and practical commentary to the Budget Code of Ukraine (2nd revised edition ed.). Kyiv: Academy of Financial Management, Ukrainian State University of Finance and International Trade.

Received for publication: $\quad$ 07.04.2014

Revision received: $\quad 10.10 .2014$

Accepted for publication: $\quad 14.10 .2014$

\section{How to cite this article?}

Style - APA Sixth Edition:

Shinkaryuk, O. V. (2015, Jan 15). State administration formation of regional human development in Ukraine. (Z. Čekerevac, Ed.) MEST Journal, 3(1), 104-113. doi:10.12709/mest.03.03.01.12

Style - Chicago Fifteenth Edition:

Shinkaryuk, Oksana V. 2015. "State administration formation of regional human development in Ukraine." Edited by Zoran Čekerevac. MEST Journal (MESTE) 3 (1): 104-113. doi:10.12709/mest.03.03.01.12.

Style - GOST Name Sort:

Shinkaryuk Oksana V State administration formation of regional human development in Ukraine [Journal] // MEST Journal / ed. Čekerevac Zoran. - Belgrade : MESTE, Jan 15, 2015. - 1 : Vol. 3. - pp. 104-113.

Style - Harvard Anglia:

Shinkaryuk, O. V., 2015. State administration formation of regional human development in Ukraine. MEST Journal, 15 Jan, 3(1), pp. 104-113.

Style - ISO 690 Numerical Reference:

State administration formation of regional human development in Ukraine. Shinkaryuk, Oksana V. [ed.] Zoran Čekerevac. 1, Belgrade : MESTE, Jan 15, 2015, MEST Journal, Vol. 3, pp. 104-113. 